\title{
EKSTRAKSI DAN KARAKTERISASI INHIBITOR KATEPSIN DARI IKAN BANDENG
}

\section{Extraction and Characterization of Cathepsin Inhibitor from Milkfish}

\author{
Tati Nurhayati*, Ruddy Suwandi, Syefri Rusyadi \\ Departemen Teknologi Hasil Perairan, Fakultas Perikanan dan Ilmu Kelautan, \\ Institut Pertanian Bogor, Kampus IPB Darmaga, Jalan Agatis, Telepon. (0251) 8622909-8622906, Faks. \\ (0251) 8622907, Bogor-Jawa Barat 16680. \\ *Korespondensi: nurhayati7870@yahoo.com \\ Diterima 10 Februari 2015/Disetujui 13 April 2015
}

\begin{abstract}
Abstrak
Enzim proteolitik terdistribusi di semua jenis organisme termasuk ikan. Sistein protease merupakan kelompok terbesar dan termasuk katepsin lisosom yang terbukti dapat menyebabkan pelunakan dan degradasi protein miofibrillar. Aktivitas protease diatur dengan inhibitor endogen. Penelitian ini bertujuan untuk melakukan optimasi ekstraksi inhibitor katepsin dari kulit, otot, dan jeroan ikan bandeng, untuk memurnikan secara parsial inhibitor katepsin dari sumber yang dipilih, dan untuk mempelajari karakteristik inhibitor katepsin. Inhibitor katepsin dapat diekstrak dengan baik dari daging ikan bandeng dan dimurnikan secara parsial menggunakan ammonium sulfat 70\%. Karakteristik inhibitor katepsin memiliki suhu optimum $40^{\circ} \mathrm{C}$ dan $\mathrm{pH}$ optimum 8 . Ion-ion logam menurunkan aktivitas inihibitor protease kecuali ion logam $\mathrm{Mn}^{2+}$ dan $\mathrm{Na}^{+} 1 \mathrm{mM}$.
\end{abstract}

Kata kunci: Inhibitor protease, katepsin, karakterisasi, purifikasi parsial

\begin{abstract}
Proteolytic enzyme is distributed acros all organism including fish. Cysteine proteases are the largest group of proteolytic enzyme. Lysosomal cathepsin, one of cysteine protease enzyme, cause softening and degradation of myofibril protein and it's activity is regulated by endogenous inhibitors. The purposes of this study were to optimize the extraction cathepsin inhibitors from the skin, muscles, and viscera of fish, to partially purify the cathepsin inhibitors of selected sources, and to study the characteristics of the cathepsin inhibitor. The cathepsin inhibitor could be extracted from muscle fish and partially purified using ammonium sulfate of $70 \%$. The purified cathepsin inhibitor had optimum temperature at $40^{\circ} \mathrm{C}$ and the optimum at $\mathrm{pH}$ 8. Metal ions decreased the activity of the protease inhibitor, except $1 \mathrm{mM}$ of metal ion $\mathrm{Mn}^{2+}$ and $\mathrm{Na}^{+}$.
\end{abstract}

Keywords: Cathepsin, characterization, partial purification, protease inhibitor

\section{PENDAHULUAN}

Proses penurunan mutu ikan segar terutama diawali dengan proses perombakan oleh aktivitas enzim yang secara alami terdapat di dalam ikan. Salah satu jenis enzim yang berperan penting dalam proses kemunduran mutu ikan adalah enzim-enzim pengurai protein (enzim proteolitik) yang menguraikan protein menjadi pepton, peptida dan asam-asam amino. Hidrolisis protein oleh suatu protease misalnya katepsin, kalpain dan kolagenase dapat menyebabkan timbulnya akumulasi metabolit, perubahan citarasa, dan pelunakan tekstur, terbentuknya komponen volatil serta peningkatan jumlah bakteri yang akhirnya menimbulkan kebusukan.

Aktivitas proteolitik menyebabkan perubahan fungsional dan sifat organoleptik dari daging ikan. Katepsin merupakan kelompok dari sistein protease diantaranya katepsin B dan L yang dapat menyebabkan terjadinya pelunakan daging (softening) 
pada ikan (Ladrat et al. 2006). Katepsin L ditemukan pada sebagian besar proteinase termasuk penyebab degradasi protein miofibril pada surimi ikan pacific whitening. Penambahan inhibitor protease seperti sistein pada surimi dapat mengurangi penurunan kekuatan gel melalui penghambatan sistein protease endogenous (Morrissey et al. 1995).

Interaksi antara sistein protease dan inhibitornya telah menjadi tujuan beberapa penelitian pada dua dekade ini. Inhibitor spesifik dari sistein protease sangat dibutuhkan untuk mencegah terjadinya proteolitik yang destruktif dan juga dapat dimanfaatkan pada proses terapi dan pada berbagai bahan penelitian. Pengertian yang mendalam pada interaksi sistein proteinase dan inhibitornya dapat memberikan informasi penting untuk mengkontrol aktivitas proteolitik (Hultman 2003). Inhibitor sistein proteinase yang secara luas tersebar pada jaringan hewan dan cairan tubuh, merupakan suatu molekul protein yang terdiri dari 100 sampai 120 deret asam amino dengan adanya jembatan disulfida dan residu karbohidrat (Otto dan Schirmeister 1997).

Inhibitor protease pada ikan diperkirakan dapat melakukan perlindungan dari mikrooganisme dan proses embriogenesis pada regulasi pertumbuhan awal embrio. Inhibitor seperti sistein juga dapat berperan sebagai pertahanan melawan protease virus yang dibutuhkan untuk replikasi virus (Ustadi et al. 2005). Inhibitor protease alami telah berhasil dipurifikasi seperti sistatin yang dipurifikasi dari telur ikan glassfish (Ustadi et al. 2005), cairan ovarian ikan nila, telur ikan salmon, kulit ikan atlantik salmon dan ikan cod (Olonen 2004), plasma ikan chum salmon (Li et al. 2008), dan purifikasi inhibitor tripsin dari telur ikan skipjack cakalang (Choi et al. 2002).

Ikan bandeng (Chanos chanos, Forskal) seperti halnya mahluk hidup lainnya merupakan sumber enzim dan inhibitor alami yang dapat berada dalam sel (intraseluler) dan melekat pada membran atau berada di luar sel (ekstraseluler). Permintaan yang kuat terhadap inhibitor protease alami yang dapat digunakan untuk mencegah proses kemunduran pada daging ikan dan produk berbasis surimi (Ustadi etal.2005). Beberapa inhibitor protease telah dicoba ditambahkan ke dalam daging ikan untuk menjelaskan peranan enzim pada proses pelunakan daging saat post mortem. Kubota et al. (2001) menyatakan bahwa EDTA, pengkelat ion logam dan phenantroline (inhibitor spesifik metalloprotease) dapat menekan terjadinya pelunakan daging ikan flounder. Penelitian ini bertujuan optimasi ekstraksi PI dari kulit, otot, dan jeroan ikan bandeng, untuk memurnikan secara parsial inhibitor katepsin dari sumber yang dipilih, dan untuk mempelajari karakteristik inhibitor katepsin.

\section{BAHAN DAN METODE \\ Bahan dan Alat}

Bahan utama yang digunakan pada penelitian adalah ikan bandeng (Chanos chanos, Forskal). Ikan bandeng dibawa dalam keadaan hidup ke laboratorium dan dipreparasi untuk diambil bagian daging, kulit, dan jeroan. Bahan-bahan kimia yang digunakan untuk ekstraksi dan analisis adalah tris base (Applichem), asam sitrat (Applichem), ammonium sulfat $\left(\left(\mathrm{NH}_{4}\right)_{2} \mathrm{SO}_{4}\right)$, sodium fosfat (Merck), sodium azida (Merck), 2-merkaptoetanol (Sigma), asam trikloro asetat (TCA) (Merck), tirosin (Applichem), folin (Merck), hemoglobin (Sigma), commasive brilliant blue R-250 (Sigma), bovine serum albumin (BSA) (Applichem). Logamlogam yang digunakan untuk karakterisasi enzim yaitu $\mathrm{CaCl}_{2} \mathrm{NaCl}, \mathrm{MnCl}_{2}$ dan $\mathrm{COCl}_{2}$ dari Merck. Inhibitor komersial, yaitu PMSF, EDTA dan pepstatin. Bahan untuk purifikasi digunakan DEAE sephadex A-50 dan sephadex-G100 (pharmacia). Penentuan berat molekul digunakan SDS poliakrilamida (SDSPAGE), prestained protein marker dengan berat molekul 175-7 kDa (NE Biolabs) yang terdiri dari MBP (maltose-binding protein) - $\beta$-galactosidase (175 kDa), MBP-paramyosin 
(80 kDa), MBP-CBD (chitin binding domain) (58 kDa), CBD-Mxe Intein-2CBD (46 kDa), CBD-Mxe Intein (30 kDa), CBD-BmFKBP13 $(25 \mathrm{kDa})$, lysozyme $(17 \mathrm{kDa})$, aprotinin $(7 \mathrm{kDa})$. Alat utama yang digunakan adalah spektrofotometer uv-vis (Yamato), sentrifus dingin (Sorvall), inkubator (thermoline), mikropipet (Axygen), dan elektroforesis.

\section{METODE PENELITIAN}

Ekstraksi Inhibitor Katepsin (An et al. 1995 yang dimodifikasi)

Ekstraksi inhibitor katepsin dilakukan pada bagian kulit, jeroan, dan daging ikan. Sampel sebanyak $100 \mathrm{~g}$ dihomogenasi dengan $100 \mathrm{~mL}$ akuades dingin (dibawah $4^{\circ} \mathrm{C}$ ), selanjutnya disentrifugasi dingin pada kecepatan 5.000 x g selama 30 menit. Supernatan diambil dan ditambahkan buffer McIlvaine's pH 5,5 (dibuat dari 0,2 M sodium fosfat dan $0,1 \mathrm{M}$ asam sitrat) dengan volume yang sama dengan supernatan.

Campuran diinkubasi selama 10 menit pada suhu 60,70 , dan $80^{\circ} \mathrm{C}$, selanjutnya disentrifugasi kembali pada kecepatan 7.000x g selama 15 menit. Supernatan yang diperoleh merupakan ekstrak kasar inhibitor katepsin. Aktivitas inhibitor katepsin diukur menggunakan katepsin yang diekstrak dari daging ikan bandeng sebagai substrat. Enzim katepsin diekstrak menggunakan metode Dinu et al. (2002). Konsentrasi protein ditentukan dengan metode Bradford (1976).

\section{Presipitasi Ekstrak Kasar Inhbitor Katepsin Menggunakan Ammonium Sulfat (Ustadi et al. 2005)}

Inhibitor katepsin ekstrak kasar dipresipitasi atau diendapkan menggunakan ammonium sulfat $\left(\left(\mathrm{NH}_{4}\right)_{2} \mathrm{SO}_{4}\right)$ dengan tingkat kejenuhan 30\%-80\% (w/v). Pengendapan dilakukan dengan menambahkan garam ammonium sulfat ke dalam supernatan (ekstrak kasar inhibitor katepsin) sedikit demi sedikit. Campuran didiamkan selama semalam pada suhu sekitar $4^{\circ} \mathrm{C}$, selanjutnya disentrifugasi pada kecepatan $12.000 x g$ selama 30 menit. Hasil pengendapan, yaitu presipitat dilarutkan dalam buffer A (buffer Mcllvaine's $\mathrm{pH}$ 5,5 yang dibuat dari 0,2 $\mathrm{M}$ sodium fosfat dan $0,1 \mathrm{M}$ asam sitrat).

\section{Karakterisasi Inhibitor Katepsin}

Karakterisasi inhibitor katepsin dilakukan terhadap ekstrak kasar. Karakterisasi meliputi penentuan suhu optimum, pH optimum, stabilitas panas dan $\mathrm{pH}$, serta pengaruh ion logam.

\section{Penentuan Suhu dan pH Optimum Inhibitor Katepsin}

Karakterisasi ekstrak inhibitor atepsin dilakukan pada variasi suhu $10-70^{\circ} \mathrm{C}$ dengan interval $10^{\circ} \mathrm{C}$. Karakterisasi $\mathrm{pH}$ dilakukan pada berbagai variasi $\mathrm{pH}$ yaitu 3-10 dengan pH meter merk Thermo. Aktivitas inhibitor enzim katepsin kasar diukur berdasarkan metode Dinu et al. (2002).

\section{Stabilitas Suhu dan pH Inhibitor Katepsin}

Stabilitas suhu ditentukan dengan melakukan preinkubasi inhibitor katepsin pada suhu $10-70^{\circ} \mathrm{C}$ selama 10 menit. Stabilitas $\mathrm{pH}$ ditentukan dengan melakukan preinkubasi inhibitor katepsin pada berbagai $\mathrm{pH}$ selama 10 menit pada suhu $37^{\circ} \mathrm{C}$. Aktivitas inhibitor katepsin kasar diukur berdasarkan metode Dinu et al. (2002).

\section{Pengaruh Ion Logam terhadap Inhibitor Katepsin}

Pengaruh ion logam terhadap akvitas inhibitor katepsin ditentukan dengan menambahkan ion logam $\left(\mathrm{Na}^{+}, \mathrm{Ca}^{2+}, \mathrm{Mn}^{2+}\right.$, $\mathrm{Co}^{2+}$ ) ke dalam campuran reaksi untuk assay aktivitas inhibitor katepsin. Konsentrasi inhibitor katepsin masing-masing logam adalah $1 \mathrm{mM}$ and $5 \mathrm{mM}$. Aktivitas enzim katepsin kasar diukur berdasarkan metode Dinu et al. (2002).

\section{Analisis Aktivitas Inhibitor Katepsin (Dinu et al. 2002) \\ Uji ini ditentukan dengan mengukur}


derajat penghambatan dari aktivitas enzim katepsin menggunakan substrat hemoglobin. Uji ini dimulai dengan mereaksikan ekstrak inhibitor $0,1 \mathrm{~mL}$ dengan katepsin $0,1 \mathrm{~mL}$ selama 30 menit pada suhu inkubasi $37^{\circ} \mathrm{C}$. Selanjutnya ditambahkan $0,5 \mathrm{~mL}$ dari larutan substrat hemoglobin $2 \%(\mathrm{w} / \mathrm{v})$ dan diinkubasi kembali pada $37^{\circ} \mathrm{C}$ selama 10 menit. Reaksi dihentikan dengan penambahan $2 \mathrm{~mL}$ TCA $5 \%(\mathrm{w} / \mathrm{v})$. Campuran disaring dan hasil reaksi ditambah dengan $1 \mathrm{~mL}$ pereaksi folin, kemudian campuran diukur dengan spektrofotometer pada $\lambda=750 \mathrm{~nm}$.

Pengukuran ini dilakukan bersamaan dengan pengukuran larutan blanko dan larutan standar dengan prosedur yang sama seperti larutan sampel hanya untuk larutan blanko larutan campuran enzim digantikan dengan enzim digantikan dengan akuades dan untuk larutan standar larutan campuran enzim digantikan dengan tirosin. Bersamaan dengan itu juga diperlukan uji aktivitas katepsin tanpa penambahan inhibitor dengan menggunakan enzim katepsin sebanyak 0,1 mL. Aktivitas inhibitor dihitung berdasarkan perbedaan aktivitas enzim katepsin yang ditambah dengan inhibitor dan yang tanpa inhibitor.

Aktivitas enzim katepsin dapat dihitung dengan rumus sebagai berikut:

Keterangan :

$\mathrm{UA} / \mathrm{mL}=$ jumlah tirosin yang dihasilkan per ml enzim per menit

$$
\mathrm{UA}=\frac{(\text { Abs. sampel }- \text { abs.blanko })}{(\text { Abs.stand } \mathrm{ar}-\text { abs.blanko })} \times \mathrm{P} \times \frac{1}{\mathrm{~T}}
$$

$\mathrm{P}=$ faktor pengenceran

$\mathrm{T} \quad$ = waktu inkubasi (10 menit)

Satu unit inhibitor katepsin adalah jumlah inhibitor katepsin yang mampu menghambat aktivitas protease katepsin sebesar 50\% pada kondisi pengujian.

Persentase penghambatan $=$

$$
\text { (1- } \left.\frac{\text { (aktivitas katepsin dengan inhibitor) }}{\text { (aktivitas katepsin t anpa inhibitor) }} \times 100 \%\right)
$$

\section{HASIL DAN PEMBAHASAN}

\section{Optimasi Proses Ekstraksi Inhibitor Katepsin}

Optimasi proses ekstraksi dilakukan untuk mendapatkan inhibitor protease katepsin dengan aktivitas penghambatan yang tinggi. Tahap ini dilakukan ekstraksi inhibitor pada tiga bagian ikan, yaitu pada daging, kulit, dan jeroan dengan perlakuan inkubasi ekstraksi pada suhu 60,70 , dan $80^{\circ} \mathrm{C}$. Hasil penelitian menunjukkan bahwa aktivitas terbaik diperoleh pada ekstrak daging pada waktu suhu inkubasi ekstraksi $80^{\circ} \mathrm{C}$, sedangkan untuk ekstrak dari jeroan tidak menunjukkan adanya aktivitas penghambatan protease katepsin. Hasil penghambatan ekstrak inhibitor ikan bandeng dapat dilihat pada Gambar 1.

Ekstrak inhibitor dari daging mempunyai aktivitas penghambatan tertinggi dibandingkan dari bagian kulit dan jeroan, yaitu $87,84 \%$. Ekstrak jeroan menunjukkan aktivitas inhibitor yang negatif, hal ini kemungkinan besar dalam jeroan masih banyak mengandung enzim protease lain yang aktif dan terekstrak sehingga kandungan inhibitor yang dihasilkan lebih sedikit bahkan tidak mengandung inhibitor, atau metode ekstraksi ini tidak tepat untuk mengekstrak inhibitor katepsin dari jeroan ikan.

Ekstrak inhibitor dari kulit ikan pada suhu ekstraksi $80^{\circ} \mathrm{C}$ menunjukkan aktivitas yang cukup tinggi, yaitu 77,72\%. Hasil beberapa penelitian lain menunjukkan adanya inhibitor protease pada kulit, yaitu penelitian Ylonen et al. (2002) yang melakukan pemurnian inhibitor dari kulit ikan wolffish dan atlantic cod, serta penelitian Olonen (2004), melakukan pemurnian inhibitor dari kulit ikan salmon. Kedua penelitian tersebut berhasil memurnikan inhibitor protease berupa kininogen yang termasuk inhibitor sistein protease. Penelitian Olonen et al. (2003), juga menemukan inhibitor sistein protease tipe baru berupa salarin dari ikan atlantic salmon (Salmo salar L.) dan ikan arctic charr (Salvelimus alpinus). 


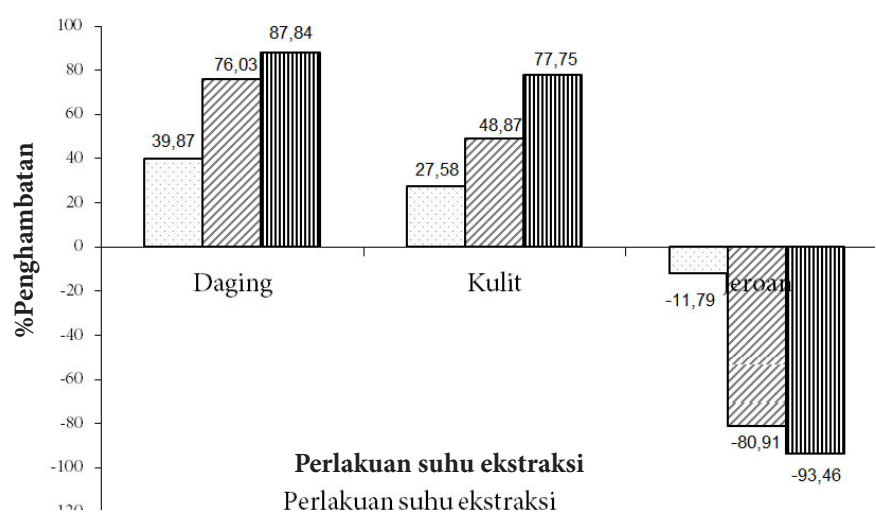

(A)

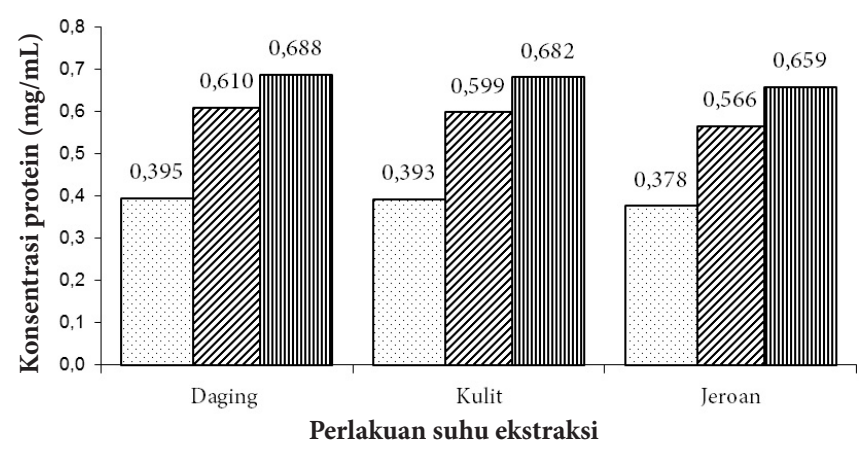

(B)

Gambar 1 Persen (\%) penghambatan aktivitas katepsin (A) dan konsentrasi protein ekstrak (B) inhibitor ikan bandeng $(\square)$ suhu $60^{\circ} \mathrm{C},(\square)$ suhu $70^{\circ} \mathrm{C}$, $(\square)$ suhu $80^{\circ} \mathrm{C}$.

Gambar 2 menunjukkan bahwa ekstrak inhibitor dari daging mengandung protein lebih tinggi dari pada ekstrak inhibitor dari kulit, kecuali pada eksrak inhibitor jeroan ikan bandeng. Bandeng merupakan ikan herbivora sehingga jeroannya masih banyak pengotor dari sisa makanan yang dapat terekstrak. Perlakuan inkubasi dari suhu $60^{\circ} \mathrm{C}$ sampai suhu $80^{\circ} \mathrm{C}$ selama 10 menit dapat menurunkan konsentrasi protein. Sifat enzim dan protein yang mudah mengalami kerusakan (terdenaturasi) sehingga mengalami pengendapan. Inhibitor endogenous dari kelas inhibitor protease sistein mempunyai sifat lebih tahan panas dibandingkan dengan enzim dan protein lainnya, sehingga proses panas ini dapat memisahkan inhibitor dengan protein atau enzim lainnya.

Beberapa inhibitor protease dapat stabil setelah perlakuan panas pada suhu $95^{\circ} \mathrm{C}$ selama 15 menit, contohnya TIMPs dan sistatin (Nagase dan Salvesen 2001). Inhibitor sistein proteinase dari hewan dan mamalia berupa sistatin dibagi dalam tiga kelompok yaitu stefin, sistatin dan kininogen, pada umumnya mempunyai kestabilan yang tinggi terhadap suhu tinggi (sampai $100^{\circ} \mathrm{C}$ ) (Otto dan Schirmeister 1997).

Hasil penelitian awal dari proses optimasi ekstraksi inhibitor terbaik digunakan sebagai acuan untuk tahap penelitian selanjutnya, yaitu produksi inhibitor protease katepsin dengan ekstraksi dari bagian daging ikan pada suhu ekstraksi $80^{\circ} \mathrm{C}$. Penelitian An et al. (1995) menemukan adanya inhibitor yang berikatan kompleks dengan katepsin L pada daging ikan pacific whitening dan berhasil melakukan pemisahan katepsin dengan inhibitor melalui perlakuan asam, sedangkan penelitian Ustadi et al. (2005) berhasil melakukan pemurnian inhibitor dari telur ikan glassfish pada perlakuan suhu $80^{\circ} \mathrm{C}$ pada saat ekstraksi. 


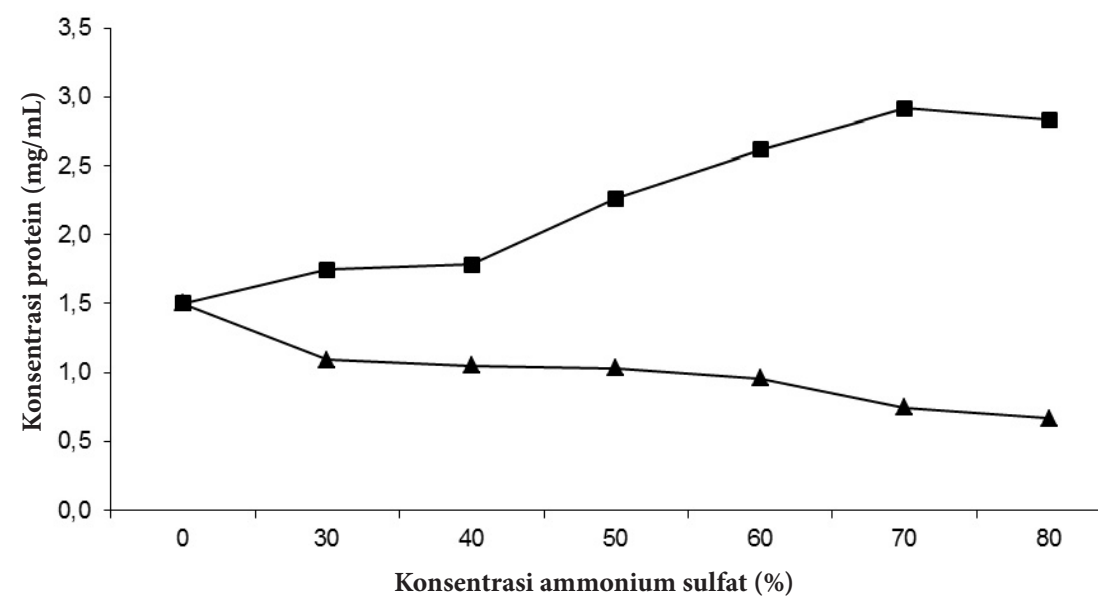

Gambar 2 Persentase (\%) aktivitas penghambatan inhibitor katepsin ikan bandeng setelah pengendapan ammonium sulfat - - endapan, - $-\mathbf{\Delta}$ - supernatan

\section{Produksi dan Pemurnian Parsial Inhibitor Katepsin}

Proses pemurnian yang dilakukan dalam penelitian ini ada beberapa tahapan yang meliputi ekstraksi daging ikan bandeng sebagai ekstrak kasar inhibitor, presipitasi inhibitor protease menggunakan ammonium sulfat.

\section{Ekstraksi Inhibitor Katepsin}

Inhibitor katepsin diekstrak dari daging ikan bandeng dengan perlakuan ekstraksi $80^{\circ} \mathrm{C}$. Setelah diperoleh ekstrak kasar kemudian dilakukan pengendapan dengan ammonium sulfat dengan persen kejenuhan $30 \%$ sampai $80 \%$ pada suhu dibawah $4^{\circ} \mathrm{C}$. Tujuannya untuk memisahkan dan memurnikan inhibitor protease dari proteinprotein lain yang terdapat pada ekstrak kasar inhibitor sehingga diharapkan inhibitor tersebut akan mempunyai aktivitas yang lebih tinggi dibandingkan ekstrak kasar. Aktivitas penghambatan inhibitor dari ekstrak ikan bandeng terhadap protease katepsin dan konsentrasi protein setelah mengalami pengendapan dengan ammonium sulfat disajikan pada Gambar 2. Hasil pengendapan dengan aktivitas penghambatan tertinggi digunakan untuk tahap dialisis.

Berdasarkan Gambar 2 dapat dilihat adanya peningkatan aktivitas penghambatan inhibitor hasil endapan (pelet) pada beberapa tingkat konsentrasi ammonium sulfat. Aktivitas persen penghambatan optimum terdapat pada hasil endapan dengan konsentrasi ammonium sulfat $70 \%$.

Hasil presipitasi pada kedua ekstrak inhibitor menyebabkan penurunan kadar protein dalam supernatan, sedangkan pada hasil endapan (pelet) terjadi peningkatan konsentrasi protein. Hasil presipitasi yang mempunyai aktivitas persen penghambatan paling tinggi digunakan untuk pemurnian tahap selanjutnya. Hasil pengendapan dengan konsentrasi ammonium sulfat $70 \%$ bagian pelet merupakan ekstrak terpilih untuk dilakukan proses dialisis.

Berdasarkan Gambar 2 dapat dilihat adanya peningkatan aktivitas penghambatan inhibitor hasil endapan (pelet) pada beberapa tingkat konsentrasi ammonium sulfat. Aktivitas persen penghambatan optimum terdapat pada hasil endapan dengan konsentrasi ammonium sulfat $70 \%$.

Hasil presipitasi pada kedua ekstrak inhibitor menyebabkan penurunan kadar protein dalam supernatan, sedangkan pada hasil endapan (pelet) terjadi peningkatan konsentrasi protein. Hasil presipitasi yang mempunyai aktivitas persen penghambatan paling tinggi digunakan untuk pemurnian tahap selanjutnya. 


\section{Karakterisasi Inhibitor Katepsin}

Faktor-faktor utama yang mempengaruhi aktivitas enzim adalah konsentrasi enzim, substrat, produk, senyawa inhibitor dan aktivator, $\mathrm{pH}$, jenis pelarut yang terdapat pada lingkungan, kekuatan ion, dan suhu (Suhartono 1989). Tujuan karakterisasi inhibitor katepsin ini untuk mengetahui kondisi optimum dari kerja inhibitor enzim. Karakterisasi dilakukan pada ekstrak kasar inhibitor ikan bandeng. Karakterisasi meliputi penentuan suhu dan $\mathrm{pH}$ optimum, stabilitas panas dan $\mathrm{pH}$, juga karakterisasi untuk mengetahui pengaruh beberapa ion logam terhadap ekstrak inhibitor katepsin.

\section{Suhu Optimum}

Inhibitor protease katepsin memiliki aktivitas maksimum pada suhu tertentu. Aktivitasnya akan meningkat seiring dengan peningkatan suhu sehingga mencapai suhu optimum. Kenaikan suhu yang lebih lanjut akan menyebabkan aktivitas menurun. Suhu optimum inhibitor katepsin, yaitu $40^{\circ} \mathrm{C}$ (Gambar 3).

Ekstrak inhibitor protease katepsin masih mempunyai aktivitas yang cukup tinggi sampai suhu $70^{\circ} \mathrm{C}$. Pada saat suhu dinaikkan, maka akan menyebabkan peningkatan aktivitas inhibitor hinggga mencapai maksimum dan jika dilanjutkan terus naik maka akan menyebabkan penurunan aktivitas inhibitor dengan pola yang berbeda pada setiap bentuk inhibitor. Inhibitor proteinase sistein dapat bersifat termostabil atau stabil pada suhu tinggi karena adanya asam amino hidrofobik, jembatan disulfida, dan intensitas interaksi elektrostatik. Rantai samping dari asam amino yang bersifat elektrostatik (bermuatan) misalnya asam aspartat, asam glutamat, dan arginin menyebabkan struktur enzim dan inhibitor protease lebih kaku sehingga sangat tahan terhadap perubahan suhu yang cukup tinggi.

Suhu mempengaruhi laju reaksi katalisis inhibitor enzim dengan dua cara. Pertama, kenaikan suhu akan meningkatkan laju reaksi inhibitor enzim sampai batas tertentu. Peningkatan suhu yang berlebih akan berpengaruh terhadap perubahan konformasi substrat (enzim) sehingga sisi aktif substrat (enzim) mengalami hambatan untuk memasuki sisi aktif inhibitor enzim, dan dapat menurunkan aktivitas inhibitor enzim. Kedua, peningkatan energi termal molekul yang membentuk struktur protein inhibitor enzim itu sendiri akan menyebabkan rusaknya interaksi nonkovalen seperti ikatan hidrogen, ikatan van der walls, ikatan hidrofobik, dan interaksi elektrostatik yang menjaga struktur tiga dimensi inhibitor enzim secara bersamasama, sehingga inhibitor enzim mengalami denaturasi. Denaturasi protein menyebabkan struktur lipatan inhibitor enzim membuka pada bagian permukaannya sehingga sisi aktif inhibitor enzim berubah dan sebagai akibatnya akan terjadi penurunan aktivitas inhibitor enzim (Hames dan Hoper 2000).

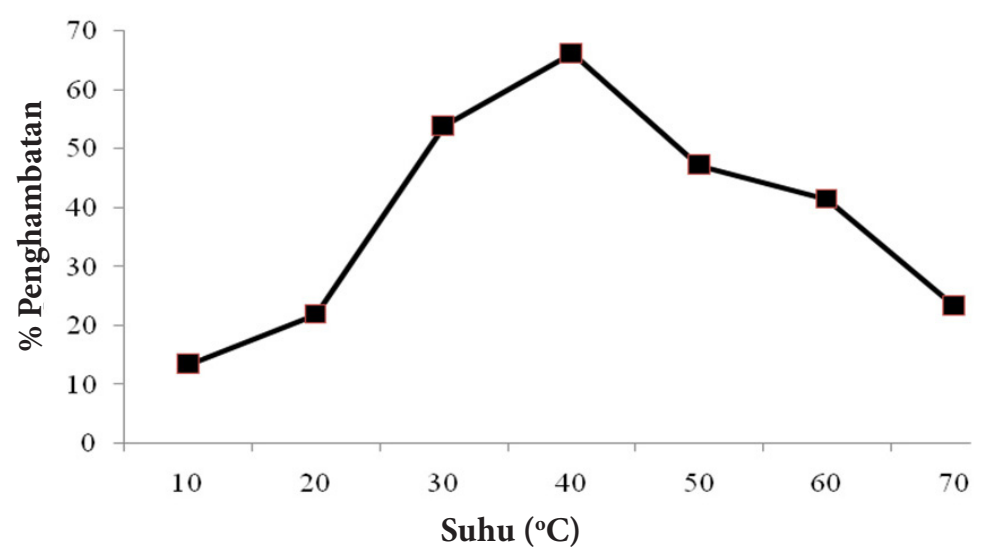

Gambar 3 Persentase (\%) penghambatan inhibitor protease ekstrak kasar ikan bandeng pada suhu $10-70{ }^{\circ} \mathrm{C} .(\square)$ inhibitor bandeng, (匹) inhibitor patin 


\section{pH Optimum}

Semua reaksi enzim dipengaruhi oleh $\mathrm{pH}$ medium tempat reaksi terjadi. Setiap enzim memiliki $\mathrm{pH}$ optimum yang khas, yaitu $\mathrm{pH}$ yang menyebabkan aktivitas maksimal. Profil aktivitas $\mathrm{pH}$ enzim menggambarkan $\mathrm{pH}$ pada saat pemberi dan penerima proton yang penting pada sisi katalitik enzim berada pada tingkat ionisasi yang diinginkan. Namun pada $\mathrm{pH}$ tertentu (ekstrim) dapat menyebabkan enzim terdenaturasi yang menyebabkan enzim kehilangan aktivitas biologisnya (Lehninger 1993).

Inhibitor katepsin yang merupakan protein mengikuti sifat-sifat protein yang mempunyai konstanta disosiasi pada gugus asam maupun basa terutama pada gugus residu terminal karboksil dan terminal aminonya. Perubahan aktivitas inhibitor protease dapat terjadi akibat adanya perubahan ionisasi pada gugus ionik inhibitor pada sisi aktifnya maupun sisi lain yang secara tidak langsung mempengaruhi sisi aktif. Gugus ionik berperan dalam menjaga konformasi sisi aktif dalam mengikat substrat (enzim) (Nurhayati 2006). Gugus fungsional pada sisi aktif yang dapat terionisasi, memegang peranan penting pada suatu reaksi katalis enzim. Reaksi pengikatan dan pelepasan ion hidrogen pada gugus fugsional tersebut dapat dianggap sebagai reaksi antara enzim dengan suatu ligan secara umum (logam, asam, atau molekul lain) (Suhartono 1989).
Gambar 4 menunjukkan bahwa $\mathrm{pH}$ optimum inhibitor protease katepsin dalam bentuk ekstrak kasar maupun setelah pengendapan dengan ammonium sulfat adalah 8. Ekstrak inhibitor dari ikan bandeng maupun ikan patin juga mempunyai $\mathrm{pH}$ optimum yang sama, berada pada kisaran $\mathrm{pH}$ 7-9. Kisaran $\mathrm{pH}$ ini menunjukkan bahwa ekstrak inhibitor katepsin termasuk inhibitor protease alkalin atau bersifat basa.

Penelitian yang lain menunjukkan bahwa inhibitor protease seperti sistatin mempunyai aktivitas penghambatan pada kisaran $\mathrm{pH}$ alkalin. Ustadi et al. (2005) menunjukkan ekstrak inhibitor protease dari telur ikan glassfish mempunyai aktivitas yang tinggi pada kisaran $\mathrm{pH}$ 7-9 dan optimum pada $\mathrm{pH}$ 8. Penelitian oleh Li et al. (2008) inhibitor sistein protease dari plasma ikan chum salmon menunjukkan aktivitas pada $\mathrm{pH}$ 6,0 -9,0 dan optimum pada $\mathrm{pH} 7,0$.

\section{Pengaruh Ion Logam terhadap Aktivitas Inhibitor}

Aktivator dan inhibitor secara kimiawi tidak dapat dibedakan, namun dapat dibedakan setelah berinteraksi dengan enzim. Aktivator berikatan dengan enzim dan menyebabkan kenaikan kecepatan reaksi enzim, sedangkan inhibitor berikatan dengan enzim dan menyebabkan penurunan kecepatan reaksi (Suhartono 1989). Beberapa ion logam mempengaruhi aktivitas enzim

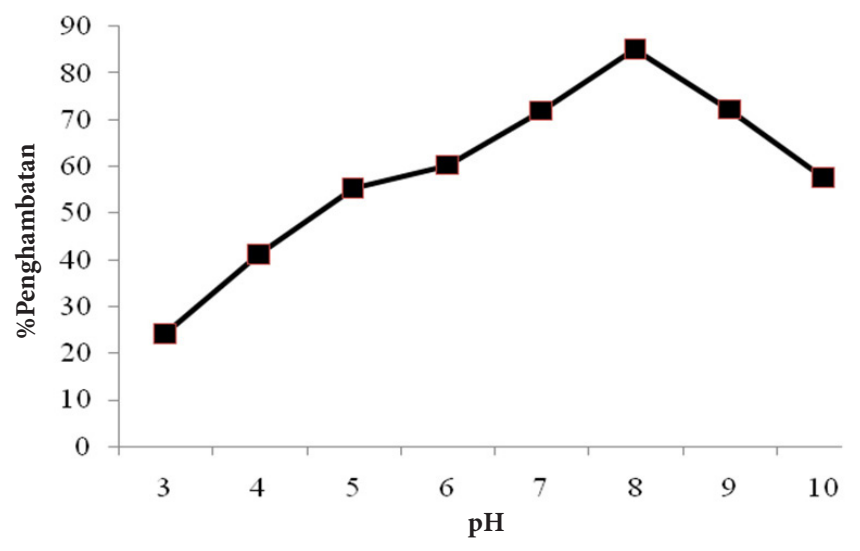

Gambar 4 Persentase (\%) penghambatan inhibitor protease ikan bandeng pada $\mathrm{pH}$ 3-10 
maupun inhibitor yang merupakan protein. Ion logam ini ada yang membantu pengikatan antara enzim dengan substrat, ada yang berikatan dengan enzim secara langsung sehingga konformasi aktif enzim menjadi stabil, dan ada yang berikatan dengan inhibitor enzim sehingga mempengaruhi kerja inhibitor menghambat enzim. Gambar 5 memperlihatkan pengaruh ion logam terhadap aktivitas inhibitor katepsin.

Ion logam $\mathrm{Mn}^{2+}$ dengan konsentrasi $1 \mathrm{mM}$ dan $5 \mathrm{mM}$ dapat meningkatkan aktivitas penghambatan inhibitor, ion logam $\mathrm{Na}^{+} 1 \mathrm{mM}$ sedikit menaikkan aktivitas penghambatan, namun menurunkan aktivitas pada konsentrasi $5 \mathrm{mM}$, sedangkan $\mathrm{Ca}^{2+}$ dan $\mathrm{Co}^{2+}$ sedikit menurunkan aktivitas inhibitor baik yang konsentrasi $1 \mathrm{mM}$ maupun $5 \mathrm{mM}$. Berdasarkan penelitian Choi et al. (2002), ion logam $\mathrm{Ca}^{2+}$ menaikkan aktivitas penghambatan relatif inhibitor tripsin dari ekstrak telur ikan cakalang. Ion logam $\mathrm{Ca}^{2+}$ dapat menghubungkan antara enzim dan inhibitor. Kemungkinan yang lain yaitu $\mathrm{Ca}^{2+}$ membatasi enzim sehingga menyebabkan modifikasi struktur yang dapat menaikkan pembentukan kompleks enzim dengan inhibitor (Choi et al. 2002).

Inhibitor bandeng terjadi sebaliknya yaitu $\mathrm{Ca}^{2+}$ sedikit menurunkan aktivitas inhibitor. Adanya perbedaan sisi aktif antara inhibitor tripsin dengan inhibitor katepsin yang termasuk jenis inhibitor sistein protease, sehingga mekanisme interaksi ion logam termasuk $\mathrm{Ca}^{2+}$ dengan inhibitor dan enzim berbeda.

Beberapa enzim dan inhibitor memerlukan ion-ion tertentu untuk menjaga kestabilan aktivitasnya. Ion-ion tersebut dapat bertindak sebagai inhibitor pada konsentrasi tertentu, tetapi dapat juga menjadi aktivator pada konsentrasi yang berbeda. Ion logam dapat membentuk suatu kompleks dengan substrat dan sisi aktif enzim sehingga menggabungkan keduanya dalam bentuk aktif. Ion logam juga berfungsi sebagai senyawa penarik kuat elektron pada tahap tertentu dalam siklus katalitik (Lehninger 1993).

\section{KESIMPULAN}

Inhibitor katepsin bisa diekstrak dari daging dan kulit ikan bandeng dengan aktivitas tertinggi pada daging ikan. Inhibitor katepsin dapat dimurnikan secara parsial dengan ammonium sulfat $40 \%$. Inhibitor katepsin tersebut memiliki suhu dan $\mathrm{pH}$ optimum yaitu $40^{\circ} \mathrm{C}$ dan 8 . Ion-ion logam menurunkan aktivitas inihibitor protease kecuali ion logam $\mathrm{Mn}^{2+}$ dan $\mathrm{Na}^{+} 1 \mathrm{mM}$

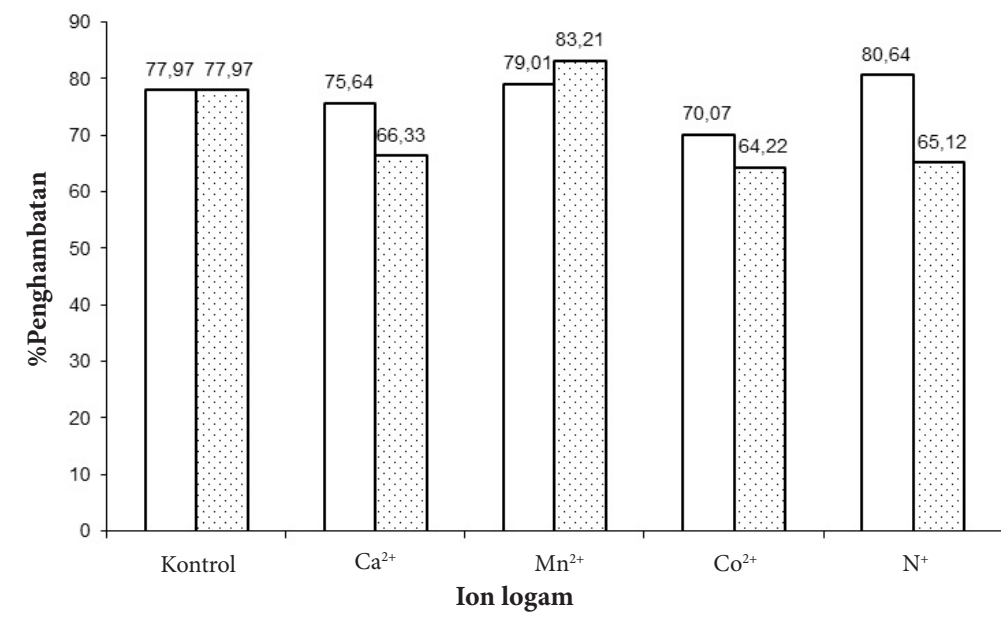

Gambar 5 Pengaruh beberapa jenis logam terhadap aktivitas penghambatan ekstrak ikan bandeng $(\square) 1 \mathrm{mM},(\square) 5 \mathrm{mM}$. 


\section{DAFTAR PUSTAKA}

Aehle W. 2004. Enzyme in Industry: Production and Application. Weinheim, German : WILEY-VCH Verlag GmbH \& Co.

An H, Peters MY, Seymour TA, Morissey MT. 1995. Isolation and activation of chatepsin L-inhibitor complex from pacific whiting (Merluccius productus). Journal Agriculture Food Chemistry 43:327-330

Aoki T. Yamashita T. Ueno R. 2000. Distribution of cathepsins in red and white muscles among fish species. Journal Fisheries Science 66(4):776-782.

APB [Amersham Pharmacia Biotech]. 2001. Affinity Chromatography: Principle and methods. Tokyo: Amersham Pharmacia Biotech $\mathrm{AB}$.

Ashie INA, Smith JP, Simpson BK. 1996. Mechanisms for controlling enzymatic reactions in foods. Critical Reviews in Food Science and Nutrition 36(1\&2), 1-30.

Bradford MM. 1967. A rapid and sensitive method for quantification of microgram quantities of protein utilizing the principle of protein dye binding. Anal Biochemistry 72:234-254.

Cao MJ, Osatomi K, Matsuda R, Ohkubo M. 2000. Purification of a novel serine proteinase inhibitor from the skeletal muscle of white croaker (Argyrosomus argentatus). Journal Biochem and Biophys Res Com 272:485-489.

Carreno FLG, Cortes PH. 2000. Use of protease inhibitors in seafood products. Dalam: Haard NF, Simpson BK, editor. Seafood Enzymes : Utilization and Influence on Postharvest Seafood Quality. New York: Marcel Dekker, Inc. hlm 531-547.

Choi JH, Park PJ, Kim SK. 2002. Purification and characterization of a trypsin inhibitor from the egg of skipjack tuna Katsuwonus pelamis. Fisheries Science 68:1367-1373.

Creighton T. 1997. Proteins : Structures and Molecular Properties $2^{\text {nd }}$ Ed. New York: WH Freeman and Co.

Davidson. 2001. SDS-PAGE Method. Davidson
: Departement of Biology. http://www.bio. davidson.edu/COURSES/GENOMICS/ method/SDSPAGE/SDSPAGE.html [16 Juli 2008].

Dinu D, Dumitru IF, Nechifor MT. 2002. Isolation and characterization of two chatepsin from muscle of Carassius auratus gibelio. Roum. Biotecnol. Lett 7(3):753 : 758.

Dubey VK, Pande M, Singh BK, Jagannadham MV. 2007. Papain-like proteases: Applications of their inhibitors. African Journal of Biotechnology 9(6):1077-1086.

Haard NF. 2000. Seafood enzymes: the role of adaptation and aother intraspesific factor. Dalam: Haard NF, Simpson BK, editor. Seafood Enzymes: Utilization and Influence on Postharvest Seafood Quality. New York: Marcel Dekker, Inc. hlm 531-547.

Hames BD, Hooper NM. 2000. Biochemistry: The Instant Notes. 2nd editioin. Hongkong:Spinger-Verlag.

Han Y, Yu H, Yang X, Rees HH, Liu J, Lai R. 2008. A serine proteinase inhibitor from frog eggs with bacteriostatic activity. Journal Comp Biochem and Physi, Part B 149:58-62.

Hultmann L. 2003. Endogenous proteolitic enzymes: Studies of their impact on fish muscle protein and texture. [thesis]. Faculty of Natural science and Technology. Norwegia.

Ismail A, Poernomo A, Sunyoto P, Wedjatmiko, Dharmadi, Budiman RAI. 1994. Pedoman Teknis Usaha Pembesaran Ikan Bandeng di Indonesia. Seri Pengembangan Hasil Penelitian No. 26/1993. Jakarta: Badan Litbang Pertanian.

Kolodziejska I, Sikorski ZE. 1996. Neutral and alkaline muscle proteases of marine fish and invertebrates - A review. Journal of Food Biochemistry 20:349-363.

Kubota M, Kinoshita M, Kubota S, Yamashita M, Toyohara H, Sakaguchi M. 2001. Possible implication of metalloproteinases in postmortem tenderization of fish muscle. Fisheries Science 67(5):965-968.

Ladrat DC, Cheret R, Taylor R, Bagnis VV. 
2006. Trends in postmortem aging in fish: understanding of proteolysis and disorganization of the myofibrillar structure. Critical Review in Food Science and Nutrition 46(5):409-421.

Lehninger AL. 1993. Dasar-Dasar Biokimia. Jilid 1. M. Thenawidjaja, penerjemah. Jakarta: Erlangga. Terjemahan dari: Principle of Biochemistry.

Li DK, Lin H, Kim SM. 2008. Purification and Characterization of a Inhibitor sistein protease from Chum Salmon (Oncorhynchus keta) Plasma. Journal Agriculture Food Chemistry 56:106-111.

Morrissey MT, Hartley PS, An H. 1995. Proteolysis in pacific whiting and effect of surimi processing. Journal Aquaculture Food Product Technology 4(4):5-18.

Muchtadi D, Palupi NS, Astawan M. 1992. Enzim dalam Industri Pangan. Bogor : PAU Bioteknologi, IPB.

Mudjiman A. 1991. Budidaya Bandeng di Tambak. Jakarta: Penebar Swadaya.

Nagase H, Salvesen GS. 2001. Finding, purification and characterization of natural protease inhibitor. Dalam Beynon R, Bond JS, editor. Proteolitic Enzymes : A Practical Approach. Ed ke-2. New York: Oxford university press. hlm 131-147.

Nurhayati T. 2006. Pemilahan dan karakterisasi inhibitor protease dari bakteri yang berasosiasi dengan spons asal perairan pulau panggang, kepulauan seribu [disertasi]. Bogor : Sekolah Pascasarjana, Institut Pertanian Bogor.

Oliviera AS, Xavier-Filho. Sales MP. 2003. Cysteine proteinase and sistatins. An Inter. Journal Brazilian Archieve of Biology and Technology 46(1):91-104.

Olonen A. 2004. High molecular weight sistein proteinase inhibitors in Atlantic Salmon and other fish species [dissertation]. Helsinki: Protein Chemistry Laboratory and Department of Biological and Environmental Sciences. Faculty of Biosciences. University of Helsinki.

Olonen A. Kalkinen N. Paulin L. 2003. A new type of cysteine proteinase inhibitor : the salarin gene from Atlantic salmon (Salmo salar L.) and Arctic charr (Salvelimus alpinus). Biochimistry 85:677681.

Otto HH, Schirmeister T. 1997. Sistein proteases and their inhibitors. Chemistry Rev. 97(1):133-172

Rachmansyah, TonnekS, Usman. 1997. Produksi ikan bandeng super dalam karamba jaring apung di laut. Dipresentasikan pada Seminar Regional Hasil-Hasil Penelitian Berbasis Perikanan, Peternakan dan Sistem-Sistem Usaha Tani Di Kawasan Timur Indonesia, Naibonat-Kupang, 28-30 Juli 1997. hlm 22.

Rao MB, Tanksale AM, Ghatgate MS, Deshpande VV. 1998. Molecular and biotechnological aspects of microbial proteases. Microb. Mol. Biol Revw. 62 : 1092-2172.

Rosenberg IM. 1996. Protein analysis and Purification : Benchtop technique. Boston: Birkhauser.

Salvesen GS, Nagase H. 2001. Inhibition of proteolytic enzymes. Dalam Beynon $\mathrm{R}$, Bond JS, editor. Proteolitic Enzymes: A Practical Approach. Ed ke-2. New York: Oxford university press. hlm 105-129.

Shahidi F. 1994. Seafoods proteins and preparation of protein concentrates. Dalam: Shahidi F, Botta RJ, editor. Seafoods: Chemistry, Processing Technology and Quality. London: Blackie Academic \& Professional.

Soeseno S. 1988. Budidaya Ikan dan Udang dalam Tambak. Edisi kedua. Jakarta: Gramedia.

Suhartono MT. 1989. Enzim dan Bioteknologi. Bogor : PAU Bioteknologi IPB.

Suhartono MT. 1992. Protease. Bogor : PAU Bioteknologi IPB.

Ustadi, Kim KY, Kim SM. 2005. Purification and Identification of a Protease Inhibitor from Glassfish (Liparis tanakai) Eggs. Journal Agriculture Food Chemistry 53 : 7667-7672.

Westermeier R. 2005. Electrophoresis in Practice, Fourth edition. Freiburg: WILEY- 
VCH Verlag GmbH \& Co.KGaA

Wijaya R. 2005. Karakteristik Enzim serupa

Tripsin dari Cacing Tanah. [Tesis]. Bogor :

Sekolah Pascasarjana, IPB.
Ylonen A, Helin J, Bogwald J, Jaakola J. Rinne A, Kalkinen N. 2002. Purification and characterization of novel kininogen from spotted wolfish and atlantic cod. Europe Journal Biochemistry 269:2639-2646. 